\title{
РОЛЬ КЛАССНОГО РУКОВОДИТЕЛЯ КАДЕТСКОГО КЛАССА В ОБЩЕОБРАЗОВАТЕЛЬНОМ УЧРЕЖДЕНИИ
}

\section{THE ROLE OF THE CLASS TEACHER OF THE CADET CLASS IN A GENERAL EDUCATION INSTITUTION}

\section{T. Tolmacheva}

Summary: The article deals with the main aspects of the activity of the class teacher of the cadet class in a general education institution. The significance of the class teacher for students is justified and its main role in the educational process is highlighted. A description of patriotic education and its current state is presented. The basic tasks of the class teacher that characterize the formation of patriotism are listed. In addition, some forms of the development of patriotism in the educational process are studied. The main directions of educational work and extracurricular activities on the part of the class teacher are identified.

Keywords: class teacher, cadet class, education of patriotism, extracurricular educational work, conditions and types of classes.
K лассный руководитель является важной составляющей педагогического коллектива. Именно он представляется в качестве организатора деятельности детей в образовательных учреждениях. Деятельность классного руководителя позволяет сохранить, укрепить и развить взаимопонимание учеников, их родителей, педагогов и других людей, принимающих участие в образовательном процессе.

Стоит более полноценно раскрыть одну из существенных ролей классного руководителя - организацию воспитания патриотизма у учеников, а в частности, учеников кадетских классов.

Патриотическое воспитание представляет из себя особую систему мер и воздействий, которые направлены на процесс воспитания в детях положительного отношения к общественным ценностям, отдельным личностям, их деятельности, а также к явлениям общественной жизни. Академик Д.С. Лихачев писал следующее: «К патриотизму нельзя призывать - его нужно заботливо воспитывать».

На сегодняшний день Россия находится в непростом для себя историческом периоде. Самая большая опасность, которая подстерегает наше общество связана не с развалом экономики, не со сменой политической системы, а с разрушением личности. В современное время происходит доминирование материальных ценностей
Толмачева Татьяна Владимировна

Аспирант, ФГБОУ ВО «Карачаево-Черкесский государственный университет имени У.Д. Алиева»,

2. Карачаевск

tvtolmacheva@mail.ru

Аннотация: В статье рассмотрены основные аспекты деятельности классного руководителя кадетского класса в общеобразовательном учреждении. Обоснована значимость классного руководителя для обучающихся и выделена его основная роль в воспитательном процессе. Представлено описание патриотического воспитания и его современного состояния. Перечислены базовые задачи классного руководителя, характеризующие формирование патриотизма. Кроме того, изучены некоторые формы развития патриотизма в условиях образовательного процесса. Выявлены основные направления воспитательной работы и внеурочной деятельности со стороны классного руководителя.

Ключевые слова: классный руководитель, кадетский класс, воспитание патриотизма, внеурочная воспитательная работа, условия и виды занятий

над духовными, что приводит к искажению представления у людей, а в особенности молодых людей, о таких понятиях, как доброта, милосердие, великодушие, справедливость, гражданственность и патриотизм. Общий рост агрессивности и жесткости в обществе вызывает значительное повышение уровня преступности. В подростках все чаще можно наблюдать проявление эмоциональной, волевой и духовной незрелости. В настоящее время очень важно поднимать тему падения нравственных ценностей у молодежи, ведь на сегодняшний день массовая культура значительно опошлена, она работает по законам рынка через средства массовой информации, что может способствовать деформации или даже уничтожению основ человеческих ценностей. А ведь система ценностей складывалась длительное время. Она вобрала в себя опыт поколений, формирование которого осуществлялось под влиянием таких факторов как история, природа, географические особенности территории, на которой проживали народы нашей страны.

Значение патриотизма и гражданственности является весьма существенным в социальном и нравственнодуховном развитии личности. Они выступают в качестве составных элементов мировоззрения индивида, его отношения к своей стране, а также к другим нациям и народам. Лишь благодаря высоким чувствам патриотизма и национальным святыням происходит укрепление любви к родине, возникает ощущение ответственности за ее историю и независимость, за необходимость сохранять 
материальные и духовные ценности, а также происходит развитие у личности таких качеств как благородство, честь и достоинство. Воспитание человека в качестве гражданина является одной из основных задач современной образовательной системы.

Необходимо сказать, что при воспитании в гражданине патриотизма, неоценимой является в этом процессе роль классного руководителя. Он производит решение важных задач, связанных с формированием патриотизма, которые подразумевают следующие действия:

- использовать ученическое самоуправление как действенное средство для гражданского патриотического воспитания подростков;

- изучить символику государства (герб, флаг, гимн), привить уважение к символам правильного отношения;

- осуществлять воспитание, показывая примеры подвигов советского народа в Великой Отечественной войне;

- изучать историю своей малой Родины;

- познавать традиции своего народа, его культурные ценности, обычаи;

- развивать и непосредственно участвовать в волонтерстве, оказывать возможную помощь ветеранам войны и труда;

- прививать чувства сопереживания к людям, нуждающихся в этом, а также оказывать им посильную помощь;

- использовать все возможные средства для воспитания гражданственности и патриотизма, включая школьный музей, экскурсии;

- посещать тематические выставки, активно участвовать в проводимых государственных праздниках.

Классный руководитель может благодаря классным часам, тематическим мероприятиям, экскурсиям, беседам и другим приемам, помочь подростку осуществить понимание понятий родины, добра и зла, уважения, толерантности и других понятий. Классный руководитель способен вызвать в учениках заинтересованность в том, чтобы изучать историю родной страны, знакомиться с культурой, осознавать перспективы государства, приходить к пониманию того, как каждый гражданин может повлиять на будущее своей страны.

Патриотизм - важная черта всесторонне развитой личности [8]. С уверенностью можно сказать, что на классных руководителях лежит весомая ответственность, которая заключается в воспитании поколения благородных, готовых к подвигу людей, которых смело можно будет называть патриотами.

Школьный возраст - это самый подходящий возраст, для того чтобы осуществить практически полноценное формирование патриотических чувств и качеств человека [16]. Именно в период школьного возраста происходит такой важный процесс как становление личности. Ученики в это время впитывают в себя большое количество информации. Поэтому в этот период необходимо формировать в детях правильную жизненную позицию, а также нужно пытаться отгораживать их от отрицательного влияния со стороны окружения. И конечно же, на данном этапе жизни является необходимым воспитание такого гражданина России, который будет нравственным, ответственным, инициативным и компетентным. Поэтому стоит повториться, что одна из основных целей, которая стоит перед классным руководителем, заключается в том, чтобы сформировать гражданские и патриотические качества личности у учеников, взрастить в них активную жизненную позицию.

Хоть и все педагоги имеют одну цель - учить, развивать, воспитывать, но подход к этой цели осуществляется разными путями. Патриотическое воспитание необходимо рассматривать в единой системе образования и воспитания детей и взрослых, реализовывая его благодаря различным формам учебного и воспитательного процессов: учебным предметам, системе воспитательной работы, внеурочной деятельности, дополнительному образованию и другим.

Классный руководитель играет ключевую роль в создании условий для осуществления процессов саморазвития, самореализации личности подростка, а также его социализации в обществе. Кроме описанных выше задач классного руководителя, дополнительно можно выделить следующие: сформировывать и развивать коллектив класса; создавать благоприятные психолого-педагогические условия для того, чтобы у детей имелась возможность развивать себя как личность, осуществлять самоутверждение, сохранять свою неповторимость и при этом раскрывать свои уникальные способности; формировать здоровый образ жизни у детей; организовывать систему отношений с помощью разнообразных видов воспитывающей деятельности классного коллектива; защищать права и интересы обучающихся; организовывать системную работу с обучающимися в классе; формировать у подростков нравственные смыслы и духовные ориентиры; организовывать социально значимую, творческую деятельность учеников.

У классного руководителя присутствует ответственность за воспитывающую деятельность в коллективе класса. Также он осуществляет моделирование, организацию и стимулирование развития личности обучающихся. Классный руководитель в качестве своеобразного посредника между обществом и учениками осуществляет организацию системы отношений с помощью разнообразных видов деятельности коллектива класса, создание условий, позволяющих развиваться каждой 
личности, раскрывать его потенциальные способности, формировать гражданственность и патриотизм. У современных подростков часто возникает проблема выбора тех ценностей, которые нужно сделать в качестве внутренних ориентиров. Именно поэтому классный руководитель незаменим при воспитании личности, которая будет способна в любой ситуации осуществить верный выбор. Классный руководитель сопровождает личность в вырабатывании ею своей гражданской позиции.

Основное направление воспитательной деятельности заключается в том, чтобы сформировать в личности гражданско-патриотическое сознание, уважение к закону, патриотизм с помощью краеведческих материалов, истории и традиций школы, жизни известных земляков. Воплощение идей гражданственности и патриотизма можно осуществлять благодаря проведению разных мероприятий. Воспитывать патриотизм позволяют такие уроки мужества, как «Что значит быть патриотом?», «В жизни всегда есть место подвигу», круглые столы «История моей семьи в фотографиях», «Сильный характер - его можно воспитать». Также патриотическому воспитанию способствуют проведение встреч с ветеранами войны и труда, воинами-интернационалистами, экскурсии в музеи и экскурсии по памятным местам.

Основной критерий эффективности деятельности классного руководителя по гражданско-патриотическому воспитанию заключается в степени готовности и стремлении учеников выполнять свой гражданский и патриотический долг, в умении и желании обучающихся осуществлять сочетание общественных и личных интересов.

Реализация целей воспитательной работы осуществляется с помощью самих учебных занятий, внеурочной деятельности коллектива класса и внеурочных занятий групп дополнительного образования.

Осуществление внеурочной воспитательной работы проводится в соответствии с Федеральным государственным образовательным стандартом по следующим основным направлениям воспитательной работы:

- «Патриот». Это направление связано с воспитанием гражданской ответственности, духовным здоровьем учащихся, воспитанием у них патриотических чувств, формированием понимания и осознания исторического прошлого и будущего, своей непосредственной роли в жизни страны;

- «Учение». Данное направление связано, собственно, с самим процессом образования, а также с интеграцией личности с обществом, которая достигается путем реализации интересов детей и их потребностей в самосовершенствовании, самореализации, саморазвитии;

- «Здоровый образ жизни». Такое направление связано с созданием условий для нормального физического развития учеников, воспитанием негативного отношения к вредным привычкам, пропагандой физической культуры и здорового образа жизни;

- «Досуг». Это направление связано с созданием условий для раскрытия творческих способностей учеников, приобщением к истинным культурным ценностям, развитием творческой личности обучающихся в процессе культурно-досуговой деятельности.

Внеурочная воспитательная работа применительно к кадетскому классу будет осуществляться по вышеизложенным основным направлениям следующим образом:

- По направлению «Патриот» может происходить проведение: классных часов на патриотическую тему о трагедии в Беслане, ко дню вывода войск из Афганистана, о воинской доблести солдат; мероприятий по составлению летописей о выдающихся полководцах России; поисковых работ членов музея Боевой славы, Великой Победы; мероприятий, которые посвящены празднованию Великой Победы; военно-спортивных мероприятий (зарницы, смотра песни строя, велопробега); туристические походов; конкурсов по пулевой стрельбе, строевой и силовой подготовке, рукопашному бою, самбо в рамках программы «Кадетский класс»; литературно-художественных конкурсов; экскурсий по памятникам природы, по историческим местам, по городам-героям.

- По направлению «Учение» обычно осуществляется: образование (достижения обучающихся кадетского класса учебе, работа по повышению качества и классного коллектива), а также участие во Всероссийской олимпиаде школьников, в интеллектуальных конкурсах, в российских и международных конкурсах («Кенгуру», «Русский медвежонок», «Познание и творчество», «Великие путешественники»);

- В связи с направлением «Здоровый образ жизни» осуществляется посещение спортивных секций, кружков и участие в соревнованиях;

- В связи с направлением «Досуг» осуществляется совместное времяпрепровождение, участие в коллективно-творческих делах.

В повседневной жизни классный руководитель осуществляет воспитание в кадетах дисциплинированности, честности, правдивости. Классный руководитель следит за поведением учеников, которое должно соответствовать нормам поведения в обществе, а также старается следить за опрятностью кадетов и соблюдением их формы одежды.

Хорошим способом формирования гражданствен- 
ности и патриотизма может служить проведение уроков жизни, совместного просмотра фильмов, встреч с интересными людьми, экскурсий в воинские части.

И кадетское воспитание, и уроки жизни являются одним из звеньев системы формирования личности с целью подготовить его к служению Отечеству на государственном и, в первую очередь, военном поприще. Это осуществляется посредством сообщения каждому ученику понятий и стремлений, которые являются основой чувства патриотизма. Воспитание кадетов должно заключаться также в понимании и принятии кадетами таких нравственных категорий как долг, честь, порядочность. Такое воспитание зачастую может быть подвластно лишь классному руководителю.

В итоге стоит дополнительно сказать, что деятельность классного руководителя может быть значительно эффективнее, если она будет носить вариативный характер. Чтобы в воспитательной деятельности присутствовала вариативность, необходимо осуществлять: выбор приоритетных линий своих усилий таким образом, чтобы они соответствовали личным склонностям, возможностям и особенностям учащихся; формирование ученического коллектива; включение развивающей совместной деятельности и делового общения в создание системы коллектива. Учеников стоит обучить коллективной работе при придумывании дела, которое будет интересно для каждого и которое сможет дать любому ученику возможность высказать свое мнение и возможность быть услышанным, а также которое позволит распределить свои силы, способности и время таким образом, чтобы это послужило достижению общих целей. Результат такой работы будет в сплоченности, поддержки друг друга и заинтересованности каждого в делах окружающих людей. И в целом, основная педагогическая задача классного руководителя заключается в том, чтобы обеспечить личное саморазвитие учащихся, в том, чтобы у них появилось понимание самих себя, осознание своего места и своей роли среди других людей, а также в том, чтобы обучающиеся видели закономерности мира, в котором они живут, и смогли жить правильно и эффективно в соответствии с этими закономерностями.

\section{ЛИТЕРАТУРА}

1. Агапова И.А., Давыдова М.А. Мы — патриоты! Классные часы и внеклассные мероприятия: 1-11 классы / И.А. Агапова. - М.: Вако, 2006. - 368 с.

2. Беликов В.А. Философия образования личности: деятельностный аспект: монография / В.А. Беликов. - М.: Владос, 2004. - 357 с.

3. Беспятова Н.К. Военно-патриотическое воспитание детей и подростков, как средство социализации / Н.К. Беспятова, Д.Е. Яковлев. - М.: Айрис - Пресс, 2004. -192 C.

4. Болдырев Н.И. Нравственное воспитание школьников: вопросы теории / Н.И. Болдырев. - М.: АПН СССР, 1979. - 224 с.

5. Быков А.К. Патриотическое воспитание школьников при преподавании дисциплин гуманитарного цикла / А.К. Быков. - М.: Воспитание школьников, 2006. -185 c.

6. Веденева 0.А. [и др.]. Теория и практика работы классного руководителя. Учебное пособие / 0.А. Веденеева [и др.]. - М.: Мир науки, 2016. - 140 с.

7. Гелева П.А. Раздумья на путях движения России / П.А. Гелева. - М., 1993. - 204 с.

8. Гасанов 3.Т. Патриотическое воспитание граждан. / 3.Т. Гасанов. - М.: Народное образование, №6, 2005. - 59 с.

9. Дмитров А.Г. Воспитание патриотизма: сущность, задачи, методы: / А.Г. Дмитров. - М.: Триумф, 2005. - 299 с.

10. Ефремова Т.Ф. Новый словарь русского языка. Толково-словообразовательный: Св. 136000 словарных статей, около 250000 семантических единиц: В 2 т. / Т.Ф. Ефремова. - М.:Рус. яз., 2000. - 305-489 с.

11. Козырева Е.И. Школа педагога-исследователя как условие развития педагогической культуры / Е.И. Козырева // Козырева Е.И. Методология и методика естественных наук.—- Вып. 4.- Сб. науч. тр.- Омск: Изд-во ОмГПУ, 1999.- 24 с.

12. Кривых С.В. Педагогические основы патриотического воспитания школьников / С.В. Кривых. - Новокузнецк: Изд-во ИПК, 2002, 297 .

(c) Толмачева Татьяна Владимировна (tvtolmacheva@mail.ru). 